\title{
Global Biogeography of Fungal and Bacterial Biomass Carbon in Topsoil
}

Liyuan $\mathrm{He}^{1}$, Jorge Rodrigues ${ }^{2}$, Nadejda Soudzilovskaia ${ }^{3}$, Milagros Barceló ${ }^{4}$, Pal Axel Olsson $^{5}$, Changchun Song ${ }^{6}$, Leho Tedersoo ${ }^{7}$, Fenghui Yuan ${ }^{1}$, Fengming Yuan ${ }^{8}$, David Lipson $^{1}$, and Xiaofeng $\mathrm{Xu}^{1}$

${ }^{1}$ San Diego State University

${ }^{2}$ University of California Davis

${ }^{3}$ Leiden University

${ }^{4}$ Universiteit Leiden Centrum voor Milieukunde

${ }^{5}$ Lund University

${ }^{6}$ Chinese Academy of Sciences Changchun Branch

${ }^{7}$ University of Tartu

${ }^{8}$ Oak Ridge National Laboratory

May 5, 2020

\begin{abstract}
We synthesized 1323 combinations of phospholipid fatty acid-derived fungal biomass C (FBC), bacterial biomass C (BBC), and fungi:bacteria (F:B) ratio in topsoil, spanning 11 major biomes. We found that the FBC, BBC, and F:B ratio display clear biogeographic patterns along latitude and environmental gradients including mean annual temperature, mean annual precipitation, net primary productivity, root $\mathrm{C}$ density, soil temperature, soil moisture, and edaphic properties. At the biome level, the highest FBC and BBC densities are observed in tundra, at 3684 (95\% confidence interval: 1678 8084) $\mathrm{mg} \mathrm{kg}-1 \mathrm{and}$ $428\left(237^{\sim} 774\right) \mathrm{mg} \mathrm{kg}-1$, respectively. The lowest FBC and BBC densities were found in deserts, at $16.92\left(14.4^{\sim} 19.89\right) \mathrm{mg} \mathrm{kg}-1$ and $6.83\left(6.1^{\sim} 7.65\right) \mathrm{mg} \mathrm{kg}-1$, respectively. While the F:B ratio ranges from $1.8\left(1.6^{\sim} 2.1\right)$ in savanna to $8.6\left(6.7^{\sim} 11.0\right)$ in tundra. Combining an empirical model of F:B ratio with the global dataset of soil microbial biomass $\mathrm{C}$, we then produced global maps for FBC and BBC in 0-30 cm topsoil. Global stock of $\mathrm{C}$ was estimated to be $12.6\left(6.6^{\sim} 16.4\right) \mathrm{Pg} \mathrm{C}$ in $\mathrm{FBC}$ and 4.3 (0.5 10.3) $\mathrm{Pg} \mathrm{C}$ in $\mathrm{BBC}$ in topsoil. This work creates a benchmark for explicit use of microbial data in modelling biosphere-atmosphere feedbacks in a changing environment.
\end{abstract}

\section{Introduction}

Microorganisms play an essential role in soil carbon (C) and nutrient biogeochemistry and pose dramatic impacts on various ecosystem processes, including organic matter mineralization, soil formation, and nutrient availability (Högberg et al. 2001; Rillig \& Mummey 2006; Turner et al. 2013; Crowther et al. 2019). Eventually, the ultimate fate of soil C is primarily driven by soil microbes (Schimel \& Schaeffer 2012). Although the critical roles of soil microbes in global $\mathrm{C}$ and nutrient cycling have been widely recognized (Falkowski et al. 2008; van der Heijden et al.2008), the research on biogeographic distribution of fungi and bacteria is still in its infancy. Furthermore, microbial community structure is an important factor controlling $\mathrm{C}$ and nutrient biogeochemistry as bacteria and fungi differ in enzyme production (e.g., lignocellulose and cellulose), C use efficiency, and biomass stoichiometric ratios (Caldwell 2005; Six et al. 2006; Mouginot et 
al. 2014), and respond differently to multiple global change factors (Rousk \& Bååth 2007a; Rousk et al. 2009). Therefore, biogeographic patterns of bacteria and fungi provide pivotal information for understanding microbial contributions to global $\mathrm{C}$ and nutrient biogeochemistry.

Geographic distribution of microbes is driven by a suite of abiotic and biotic factors (Martiny et al. 2006; Hanson et al. 2012). Previous studies have investigated the controlling factors on microbial diversity and functions, including soil organic C (SOC), climate, and vegetation (de Vries et al. 2012). Soil moisture (SM), soil organic matter quality, and soil $\mathrm{pH}$ are among the key effectors influencing soil microbial community composition (Fierer \& Jackson 2006; Eskelinen et al. 2009; Brockett et al. 2012; Dinget al. 2015). Although these findings provide valuable information for local to regional environmental drivers and proxies of soil microbial community structure, we still lack a holistic and quantitative understanding of soil microbial biogeography and different microbial groups at the global scale. In particular, the lack of clear quantitative understanding of bacterial and fungal biogeography and their controls hinder the explicit incorporation of microbial mechanisms into climate models (DeLong et al. 2011; Wieder et al.2013; Xu et al. 2014).

\section{Materials and Methods}

\section{Data Compilation}

We used a combination of keywords, "fung*" or "bacteria*", "ratio", and "terrestrial" or "soil", to search peer-reviewed papers in Google Scholar. The papers were selected via following criteria: 1) at least one of fungal biomass, bacterial biomass, or F:B ratio and the units were clearly reported; 2) the data were extractable from tables (assessing the text) or figures (using Engauge Digitizer Version 10.7); 3) the study sites were not affected by disturbances such as fire burning, mining, and heavy metal contamination; and 4) the reported data contain 0-30 cm topsoil. Geological information of the sampling sites was recorded and used to locate the sites on the global map (Fig. 1 ). We also collected any available soil pH, mean annual precipitation (MAP), mean annual temperature (MAT), SOC and total nitrogen (TN) concentration, and soil texture, to validate the extracted data from global datasets.

Fungal and bacterial biomass were measured using a number of methods such as phospholipid fatty acid (PLFA), direct microscopy (DM), colony forming units (CFU), substrate-induced respiration (SIR), and glucosamine and muramic acid (GMA). Additionally, we included some experimental data (214) measured using PLFA from global topsoil dataset, detailed information about this dataset can be found in Bahram et al. (2018). To examine the potential biases in the measurement of fungal and bacterial biomass, we did a comparison among those methods (Table 1, Table S1 ). To compare the fungal (FBC) and bacterial (BBC) biomass C measured using different methods, we used conversion factors for PLFA (Frostegård \& Bååth 1996; Klamer \& Bååth 2004), SIR (Beare et al. 1990), CFU (Aon et al. 2001), DM (Birkhoferet al. 2008), and GMA (Jost et al. 2011) reported by previous studies. Across biomes, FBC, BBC, and F:B ratio generally follow the similar pattern using different methods. However, we found large variations in measured FBC and BBC among different methods. Specifically, compared with PLFA, SIR, and GMA, fungi were more dominant over bacteria using CFU, while DM estimated higher dominance of bacteria relative to fungi, suggesting that DM may underestimate FBC while CFU may overestimate FBC. In addition, we found overall higher FBC and BBC measured using GMA, which was largely different from the measurements using other methods. Therefore, using data generated from multiple methods in one analysis might be problematic. Finally we used PLFA data for this analysis. This selection is due to two reasons: 1) the PLFA was the most widely used approach (Materials and Methods), eventually the PLFA-derived FBC and BBC measurements account for $73 \%$ of the whole dataset; 2) the PLFA has been evaluated and proved to be the most appropriate approach for estimating FBC and BBC simultaneously (Waring et al. 2013).

The final database included the fungal and bacterial biomass data measured using PLFA from publications spanning from the late 1960s to 2018. Collectively, 1323 data points in unvegetated ground and 11 biomes (i.e., boreal forest, temperate forest, tropical/subtropical forest, grassland, shrub, savanna, tundra, desert, 
natural wetlands, cropland, and pasture) across the globe were included in the database (Fig. 1 ). Forest, grassland, and cropland contribute approximately $39 \%, 22 \%$, and $19 \%$ of the dataset, respectively, with all the other biomes together contributed $20 \%$ of the dataset. A majority of the field sites are located in North America, Europe, and Asia. There is relatively small amount of observations in South America, Africa, Russian Asia, Australia, and Antarctica. All soil samples are for 0-30 $\mathrm{cm}$ soil profile. For data points without coordinate information being reported, we searched the geographical coordinates based on the location of study site, city, state, and country. Then, the geographical information was used for locating the sampling points on the global map to extract climate, edaphic properties, plant productivity, and soil microclimate long-term data from global datasets.

\section{Climate, Plant, and Soil Data}

MAT and MAP with the spatial resolution of 30s during 1970-2000 were obtained from the WorldClim database version 2 (http://worldclim.org/version2). In addition, monthly mean SM and soil temperature (ST) during 1979-2014 were obtained from the NCEP/DOE AMIP-II Reanalysis (https://www.esrl.noaa.gov/psd/data/gridded/data.ncep.reanalysis2.gaussian.html). The global vegetation distribution data were from a spatial map of 11 major biomes: boreal forest, temperate forest, tropi$\mathrm{cal} /$ subtropical forest, mixed forest, grassland, shrub, tundra, desert, natural wetlands, cropland, and pasture, which have been used in our previous publication ( $\mathrm{Xu}$ et al. 2013). We used the data for spatial distribution of soil properties, including soil pH, sand, silt, clay, and SOC from the Harmonized World Soil Database (HWSD, https://daac.ornl.gov/cgi-bin/dsviewer.pl?ds_id=1247), while soil bulk density and TN data are from the IGBP-DIS dataset (IGBP, https://daac.ornl.gov/SOILS/guides/igbp-surfaces.html) because TN is not in HWSD. Since TN in IGBP-DIS are for the 100-cm profile as a whole, we used the factor calculated from the fraction of SOC in the top 0-30 cm with HWSD. Since SOC and soil TN exhibit large spatial heterogeneities, the variation in fine-scale variation in edaphic properties were underrepresented in global datasets. To better account for the edaphic effects on fungal and bacterial distribution, we examined the relationships of $\mathrm{FBC}, \mathrm{BBC}$, and $\mathrm{F}: \mathrm{B}$ ratio with $\mathrm{SOC}$, TN, and $\mathrm{C}: \mathrm{N}$ ratio with the data directly extracted from literatures. Due to the poor correlation between bulk density extracted from HWSD and reported bulk density in literatures, we used the same soil bulk density values for the entire top $100 \mathrm{~cm}$ soil profile from IGBP, assuming no difference in bulk density between top 0-30 cm and 30-100 cm soil profiles. Root C density $\left(\mathrm{C}_{\text {root }}\right)$ data were extracted from global dataset of 0.5 degree based on observation data (Ruesch \& Gibbs 2008; Songet al. 2017). Annual net primary productivity (NPP) was obtained from MODIS gridded dataset with the spatial resolution of 30s during 2000-2015 (http://files.ntsg.umt.edu/data/NTSG_Products/MOD17/GeoTIFF/MOD17A3/GeoTIFF_30arcsec/). We then compared the data directly extracted in literatures and those extracted from global datasets, and consistencies were found for a majority of the dataset (Fig. S1).

\section{Model Selection and Validation}

Considering the clear biogeographic patterns of FBC, BBC, and F:B ratio, we developed generalized linear models with climate (MAP and MAT), soil microclimate (ST and SM), plant (NPP and $\mathrm{C}_{\text {root }}$ ), and edaphic properties (clay, sand, soil $\mathrm{pH}$, bulk density, SOC, and TN) to tear apart the controlling factors on fungal and bacterial distribution. Based on the generalized linear model of climate, plant, edaphic properties, and soil microclimate for $\mathrm{FBC}, \mathrm{BBC}$, and $\mathrm{F}: \mathrm{B}$ ratio, over $70 \%$ of variations in $\mathrm{FBC}, \mathrm{BBC}$, and $\mathrm{F}: \mathrm{B}$ ratio can be explained by the generalized linear model, and FBC and BBC were better explained than F:B ratio (Fig. 2 ) .

Considering the higher proportion of missing data in $\mathrm{FBC}(14.8 \%)$ and $\mathrm{BBC}(16.3 \%)$ relative to $\mathrm{F}: \mathrm{B}$ ratio $(1.9 \%)$, we built an empirical model for F:B ratio with $75 \%$ of the dataset. With the generalized linear model of $\mathrm{F}: \mathrm{B}$ ratio, we did the principle component analysis to select the important factors in explaining the variations in the $\mathrm{F}: \mathrm{B}$ ratio. Based on the variations explained by each component and the cumulative variations of components, we selected 31 most important factors with emphasis on climate in explaining 
the variation in F:B ratio using stepwise regression, which explained $33.0 \%$ of the variation in $\mathrm{F}: \mathrm{B}$ ratio (Fig. S7; Table S2 ). The selected empirical model had the formula: $\log _{10}$ (F:B ratio) $=0.6789-$ $0.03402 * \mathrm{MAT}-0.000058 * \mathrm{MAP}+0.003772 * \mathrm{ST}+1.542 * \mathrm{SM}-0.00099 * \mathrm{NPP}+0.01553^{*} \mathrm{C}_{\text {root }}+0.1226 *$ bulk density $+0.05991 *$ soil $\quad$ pH- $0.03631 *$ clay- $0.0045 *$ sand $+0.002878 *$ SOC-0.01607*TN $+0.000177 *$ MAT*ST$0.03955^{*} \mathrm{MAT} * \mathrm{SM}-0.000015 * \mathrm{MAP} * \mathrm{ST}-0.000335^{*} \mathrm{MAP} * \mathrm{SM}+0.000005 * \mathrm{MAT} * \mathrm{NPP}-$

$0.001615^{*} \mathrm{MAT}^{*} \mathrm{C}_{\text {root }}+0.000001 * \mathrm{MAP} * \mathrm{NPP}+0.000007^{*} \mathrm{MAP}^{*} \mathrm{C}_{\text {root }}+0.02201 * \mathrm{MAT} *$ bulk density-0.003794*MAT*soil $\quad \mathrm{pH}+0.002188^{*} \mathrm{MAT}^{*}$ clay $+0.00013{ }^{*} \mathrm{MAT}^{*}$ sand$0.000061 * \mathrm{MAT}^{*} \mathrm{SOC}+0.00513^{*} \mathrm{MAT} * \mathrm{TN}-0.000029 * \mathrm{MAP} *$ soil $\mathrm{pH}+0.000001 * \mathrm{MAP} *$ clay $+0.000003 * \mathrm{MAP}^{*}$ sand$0.000001 * \mathrm{MAP} * \mathrm{SOC}-0.000043 * \mathrm{MAP} * \mathrm{TN}$.

After the model is developed, we used the $25 \%$ of the data that were not used in model development to validate the model that returned a high consistency (Fig. S8a). We then investigated the modeling performance of F:B ratio by comparing the model simulation and observed data in each biome (Fig. S9 ). We found the overall consistency between simulated and observed log-scaled F:B ratio, with relatively poor fit in deserts. Given the much lower BBC and FBC in deserts, this inconsistency does not bring large bias to our large-scale estimation. Additionally, we found a little overestimation of F:B ratio in croplands and pastures, indicating large uncertainties in managed systems that was caused by human activities.

\section{Mapping Global Bacterial and Fungal Biomass Carbon}

We compared the microbial biomass C in Xu et al. (2013) and the sum of FBC and BBC in this study and found a good agreement between the sum of $\mathrm{FBC}$ and $\mathrm{BBC}$ and microbial biomass $\mathrm{C}\left(\mathbf{F i g}\right.$. S8b $\left.; \mathrm{R}^{2}=0.91\right)$, indicating that the sum of $\mathrm{FBC}$ and $\mathrm{BBC}$ constitutes a constant proportion of microbial biomass, providing a feasible way to estimate FBC and BBC. Based on the microbial biomass C dataset in Xu et al. (2013) and the global map of F:B ratio, we generated the global maps of $\mathrm{FBC}$ and $\mathrm{BBC}$ and estimated global storage of FBC and BBC. The auxiliary data used included global vegetation distribution (Xu et al. 2013) and global land area database supplied by surface data map generated by Community Land Model 4.0 (https://svn-ccsmmodels.cgd.ucar.edu/clm2/trunk_tags/clm4_5_1_r085/models/lnd/clm/tools/clm4_5/mksurfdata_map/).

\section{Uncertainty Analysis}

To estimate the parameter-induced uncertainties in fungal and bacterial biomass distribution and storage, we used improved Latin Hypercube Sampling (LHS) approach to estimate the variations in F:B ratio. LHS approach is able to randomly produce an ensemble of parameter combinations with a high efficiency. This approach has been widely used in the modeling community to estimate uncertainties in model output (Haefner 2005; Xu 2010; Xu et al. 2014). First, we assumed that all parameters follow normal distribution, then we used LHS to randomly select an ensemble of 3000 parameter sets using the package of "improvedLHS" in $\mathrm{R}$ program (Table S2 ). Then we calculated the $95 \%$ confidence interval of fungal and bacterial biomass $\mathrm{C}$ density and storage for reporting (Table 2 ).

\section{Statistical Analysis}

Since FBC, BBC, and F:B ratio in our dataset did not follow normal distribution, we used log-transformation to convert them to normal distributions for subsequent statistical analysis. The mean and $95 \%$ confidence boundaries of $\mathrm{FBC}, \mathrm{BBC}$, and $\mathrm{F}: \mathrm{B}$ ratio were transformed back to the original values for reporting. To understand the variations of $\mathrm{FBC}, \mathrm{BBC}$, and $\mathrm{F}: \mathrm{B}$ ratio, we conducted generalized linear model to investigate relationships between $\mathrm{FBC}, \mathrm{BBC}$, and $\mathrm{F}: \mathrm{B}$ ratio and long-term climate (MAP and MAT), soil microclimate (ST and SM), plant (NPP and $\mathrm{C}_{\text {root }}$ ), and edaphic properties (clay, sand, soil $\mathrm{pH}$, bulk density, SOC, and TN). Then we used Akaike information criterion (AIC) as selection criteria, i.e., the smaller the AICs, the better the regression. Before conducting the generalized linear model, we tested the multicollinearity for the variables within and among each variable group, i.e., climate, soil microclimate, edaphic properties, and plant, and we did not find significant multilinearity $(\mathrm{VIF}<5)$. All statistical analyses were carried out and 
relevant figures were plotted with R3.5.3 in Mac OS X. The Fig. 1 and Fig. 3 were produced with NCAR Command Language (version 6.3.0) and ArcGIS (version 10.5), respectively.

\section{Results}

\section{Biome-level FBC, BBC, and F:B Ratio}

There are large variations in biome-level FBC, BBC, and F:B ratio (Table 1; $P<0.001$ for FBC, BBC, and F:B ratio among biomes). Deserts exhibited the lowest FBC of 16.9 (95\% range: $\left.14.4^{\sim} 19.9\right) \mathrm{mg} \mathrm{kg}^{-1}$ and $\mathrm{BBC}$ of $6.8\left(6.1^{\sim} 7.7\right) \mathrm{mg} \mathrm{kg}^{-1}$, while tundra habitats displayed the highest $\mathrm{FBC}$ of 3683.6 (1678.5 8083.9) $\mathrm{mg} \mathrm{kg}{ }^{-1}$ and BBC of $428.4\left(237.0^{\sim} 774.3\right) \mathrm{mg} \mathrm{kg}^{-1}$. Boreal forests had significantly higher FBC than tropical/subtropical forests and temperate forests (1234.0 mg kg-1 for boreal forests vs. $258.4 \mathrm{mg} \mathrm{kg}^{-1}$ for temperate forests and $451.4 \mathrm{mg} \mathrm{kg}^{-1}$ for tropical/subtropical forests). Boreal forest and tropical/subtropical forests have significantly higher BBC than temperate forests $\left(226.4 \mathrm{mg} \mathrm{kg}^{-1}\right.$ for boreal forest, $210.9 \mathrm{mg} \mathrm{kg}^{-1}$ for tropical/subtropical forest vs. $53.0 \mathrm{mg} \mathrm{kg}^{-1}$ for temperate forest), with no significant differences in BBC were found between boreal forests and tropical/subtropical forests (Table 1 ). Pastures had significantly higher FBC and BBC than grasslands $\left(632.2 \mathrm{mg} \mathrm{kg}^{-1}\right.$ soil vs. $215.2 \mathrm{mg} \mathrm{kg}^{-1}$ soil for FBC and $270.7 \mathrm{mg} \mathrm{kg}^{-1}$ soil vs. $62.7 \mathrm{mg} \mathrm{kg}^{-1}$ soil for BBC); While we did not find differences in FBC across unvegetated ground, cropland, shrub, savanna, and natural wetlands; BBC was significantly higher in wetlands than in unvegetated ground (Table 1 ).

The F:B ratio varied less across biomes, with the lowest values in savannas and greatest values in tundra habitats (1.8 for savanna vs. 8.6 for tundra). We also found significantly higher F:B ratio in boreal forests and temperate forests than that in tropical/subtropical forests ( 5.0 for boreal forest, 4.9 for temperate forest vs. 2.2 for tropical/subtropical forest). No significant differences in F:B ratio were found across natural wetlands, unvegetated grounds, deserts, and shrubs (Table 1 ).

\section{Biogeography of $\mathrm{FBC}, \mathrm{BBC}$, and $\mathrm{F}: \mathrm{B}$ ratio}

Both FBC and BBC exhibited inverse unimodal relationships with latitude, with lowest values at midlatitudes (Fig. S2a-b ; $P<0.0001$ for both $\mathrm{FBC}$ and $\mathrm{BBC}$ along latitude), whereas the $\mathrm{F}: \mathrm{B}$ ratio was positively correlated with latitude (Fig. S2c $; P<0.0001)$. Of climatic predictors, MAT showed an inverse unimodal relationship with FBC, with the lowest at $14-15^{\circ} \mathrm{C}$ (Fig. S3a ; $P<0.0001$ ). Conversely, BBC showed no significant correlation with MAT (Fig. S3b ; $P=0.19$ ). The F:B ratio showed a significantly negative linear relationship with MAT (Fig. S3c $; P<0.0001)$.

Both FBC and BBC showed unimodal relationships with MAP, with peak FBC and BBC at approximately 2100-mm $\mathrm{y}^{-1}$ and 3000-mm $\mathrm{y}^{-1}$, respectively. While F:B ratio linearly decreased with MAP (Fig. S3d-f ; $P_{\text {FBC }}<0.0001, P_{\text {BBC }}<0.0001, P$ F:B ratio $\left.<0.0001\right)$. FBC increased in a non-linear manner with SM, while BBC linearly increased with SM (Fig. S4a-b; $\left.P_{\mathrm{FBC}}<0.0001, P{ }_{\mathrm{BBC}}<0.0001\right)$. Both FBC and BBC linearly increased with ST $\left(\right.$ Fig. S4d-e; $\left.P_{\text {FBC }}<0.0001, P_{\mathrm{BBC}}<0.0001\right)$. F:B ratio increased with SM (Fig. S4c $P<0.0001)$ but decreased with ST (Fig. 4f $; P<0.0001)$.

Vegetation controls on microbial biomass $\mathrm{C}$ differed in fungi and bacteria. While $\mathrm{BBC}$ significantly increased with $\mathrm{C}_{\text {root }}\left(\right.$ Fig. S5a-b $; P_{\text {FBC }}=0.2, P$ BBC $\left.=0.00035\right)$, no significant correlation between $\mathrm{FBC}$ and $\mathrm{C}_{\text {root }}$ occurred. The $\mathrm{F}: \mathrm{B}$ ratio exhibited a unimodal correlation with $\mathrm{C}_{\text {root }}$, with the peak $\mathrm{F}: \mathrm{B}$ ratio associated with the $\mathrm{C}_{\text {root }}$ of $6.9 \mathrm{~kg} \mathrm{~m}^{-2}$ (Fig. S5c $; P<0.0001$ ). Both FBC and BBC linearly increased with NPP, while F:B ratio linearly decreased with NPP (Fig. S5d-f $\left.; P_{\text {FBC }}=0.011, P_{\mathrm{BBC}}<0.0001, P_{\text {F:B ratio }}<0.0001\right)$.

Microbial biomass was well correlated with edaphic factors. Both FBC and BBC exhibited inverse unimodal relationships with SOC, with minimum FBC and BBC at SOC of 142.1 and $222.7 \mathrm{~g} \mathrm{~kg}^{-1}$, respectively (Fig. S6a and $\left.\mathbf{b} ; P_{\mathrm{FBC}}<0.0001, P_{\mathrm{BBC}}=0.0017\right)$, while $\mathrm{F}: \mathrm{B}$ ratio linearly increased with $\mathrm{SOC}(\mathbf{F i g}$. S6c $; P$ 
$<0.0001)$. Both FBC and BBC linearly increased with $\mathrm{TN}$, while $\mathrm{F}: \mathrm{B}$ ratio exhibited unimodal relationship with TN, with the maximum F:B ratio at TN of $25.4 \mathrm{~g} \mathrm{~kg}^{-1}$ (Fig. S6d-f $; P$ FBC $<0.0001, P$ BBC $=0.011$, $\left.P_{\text {F:B ratio }}<0.0001\right)$. Both FBC and BBC showed unimodal relationships with SOC:TN (C:N) ratio, with the maximum FBC and BBC at C:N ratio of 20.1 and 17.7, respectively (Fig. S6g-h ; $P_{\text {FBC }}<0.0001, P$ $\mathrm{BBC}<0.0001$ ), while $\mathrm{F}: \mathrm{B}$ ratio showed inverse unimodal relationship with $\mathrm{C}: \mathrm{N}$ ratio, with minimum $\mathrm{F}: \mathrm{B}$ ratio at C:N ratio of 7.1 (Fig. S6i $; P$ F:B ratio $<0.0001$ ). In addition, both $\mathrm{FBC}$ and $\mathrm{BBC}$ showed inverse unimodal relationships with soil bulk density, with minimum FBC and BBC at bulk density of 1.5 and $1.4 \mathrm{~g}$ $\mathrm{cm}^{-3}$, respectively, while F:B ratio linearly decreased with bulk density (Fig. S6j-1; $P_{\text {FBC }}<0.0001, P$ BBC $\left.=0.00035, P_{\text {F:B ratio }}<0.0001\right)$. Furthermore, we found that FBC, BBC, and F:B ratio all showed inverse unimodal relationships with soil $\mathrm{pH}$, with minimum $\mathrm{FBC}, \mathrm{BBC}$, and $\mathrm{F}: \mathrm{B}$ ratio at soil $\mathrm{pH}$ of 7.5, 7.4 and 6.3, respectively (Fig. S6m-o $; P_{\mathrm{FBC}}<0.0001, P_{\mathrm{BBC}}<0.0001, P_{\mathrm{F}: \mathrm{B} \text { ratio }}<0.0001$ ). We also found the highest FBC and BBC in clayey s, but the highest F:B ratio in sandy soil (Fig. 6p-r; $P_{\mathrm{FBC}}<0.0001, P_{\mathrm{BBC}}<$ $\left.0.0001, P_{\text {F:B ratio }}<0.0001\right)$.

\section{Quantitative Assessment of Controls on Microbial Biogeography}

We constructed generalized linear models to disentangle the effects of climate (MAP and MAT), plant (NPP and $\mathrm{C}_{\text {root }}$ ), soil microclimate (SM and ST), and edaphic properties ( $\mathrm{SOC}, \mathrm{TN}$, soil $\mathrm{pH}$, clay, sand, and bulk density), on the variation in $\mathrm{FBC}, \mathrm{BBC}$, and $\mathrm{F}: \mathrm{B}$ ratio. The variance inflation factor (VIF) test revealed no multicollinearity among variables. Environmental factors in total explained a large proportion of variation in microbial biomass ( $81.9 \%$ for FBC, $84.8 \%$ for BBC, and $71.2 \%$ for F:B ratio) (Fig. 2 ). Notably, the edaphic properties were the most important drivers in $\mathrm{FBC}$ and $\mathrm{BBC}$, with $66.4 \%$ and $70.4 \%$ of the variations in $\mathrm{FBC}$ and BBC being explained by edaphic properties and the interaction with other factors, respectively (Fig. 2a-b ). Complex interactions between the groups of variables explained $23.7 \%$ of the variation in FBC (Fig 2a ). In contrast, variation in $\mathrm{BBC}$ was explained primarily by the interactions between edaphic properties and climate (13.9\%), multiple interactions (11.91\%), and edaphic properties alone (10.22\%). Climate was the most important predictor of $\mathrm{F}: \mathrm{B}$ ratio. Climate alone explained $11.6 \%$, and climate interactions with other variables explained $35.5 \%$ of the variation in the F:B ratio (Fig. 2c ).

\section{Global Carbon Storage in Fungal and Bacterial Biomass}

Based on our findings of environmental controls on $\mathrm{FBC}$ and $\mathrm{BBC}$ at the biome and global scales, we further developed an empirical model for F:B ratio considering the higher proportion of missing data in FBC (14.8\%) and BBC (16.3\%) relative to F:B ratio (1.9\%) (Materials and Methods; Table S2 ). Combined with a global microbial biomass $\mathrm{C}$ dataset reported by $\mathrm{Xu}$ et al. (2013), we further produced global maps of BBC and FBC in topsoil (Fig. 3 ). The global FBC and BBC are estimated to be $12.56\left(6.64^{\sim} 16.42\right) \mathrm{Pg} \mathrm{C}$, and $4.34\left(0.47^{\sim} 10.26\right) \mathrm{Pg} \mathrm{C}$ in BBC for 0-30 cm topsoil. Taking the global estimates of SOC (684 $724 \mathrm{Pg} \mathrm{C}$ in $0-30 \mathrm{~cm}$ ), approximately $1.8 \%$ and $0.6 \%$ of SOC is stored in soil fungi and bacteria, respectively. The highest FBC density occurs in northern high-latitude regions while lowest values are characteristic of low-latitude regions (Fig. 3b ). On the contrary, the highest BBC was found in high-latitude and equatorial regions, and the lowest in mid-latitude regions (Fig. 3c) .

At biome-level, boreal forests stored large FBC (3.60 Pg C) and tropical/subtropical forests had the largest BBC storage (0.85 Pg C), while shrub contributed least to both FBC and BBC (0.39 Pg C for FBC and 0.14 $\mathrm{Pg} \mathrm{C}$ for BBC) (Table 2 ). Although boreal forests do not occupy the Earth's largest surface area (11.82 million $\mathrm{km}^{2}$ ), the high FBC density contributes to its prominent FBC storage. The large microbial C storage in pasture was primarily due to its large area $\left(27.0\right.$ million $\left.\mathrm{km}^{2}\right)$. Tropical/subtropical forests have relatively high $\mathrm{BBC}$ density, along with the second largest area $\left(16.44\right.$ million $\left.\mathrm{km}^{2}\right)$, tropical/subtropical forests thus stored the largest $\mathrm{BBC}$ across the globe. The smallest $\mathrm{FBC}$ and $\mathrm{BBC}$ storage in shrub was primarily due to its small area (8.11 million $\mathrm{km}^{2}$ ) and the low FBC and BBC densities (48.06 $\mathrm{g} \mathrm{C} \mathrm{m}^{-2}$ for FBC and $17.31 \mathrm{~g} \mathrm{C}$ $\mathrm{m}^{-2}$ for $\left.\mathrm{BBC}\right)$. The small $\mathrm{FBC}$ and $\mathrm{BBC}$ storage in desert primarily resulted from their low $\mathrm{FBC}$ and $\mathrm{BBC}$ densities (Fig S5 ), while the small FBC and BBC storage in tundra and natural wetland may be due to 
the small area (5.75 million $\mathrm{km}^{2}$ for tundra and 6.91 million $\mathrm{km}^{2}$ for natural wetlands). Eventually tundra has high densities of FBC and BBC (226.96 $\mathrm{g} \mathrm{C} \mathrm{m}^{-2}$ for $\mathrm{FBC}$ and $32.65 \mathrm{~g} \mathrm{C} \mathrm{m}^{-2}$ for BBC).

\section{Discussion}

\section{Biogeographic Patterns of Microbial Properties}

We found significant biogeographic patterns of fungi, bacteria and their balance in topsoil along latitude, climate (MAP and MAT), plant (NPP and $\mathrm{C}_{\text {root }}$ ), soil microclimate (SM and ST), and edaphic factors (SOC, TN, C:N ratio, soil pH, soil texture, and bulk density) (Fig. S2-6 ). Some of those have been reported in previous studies (Fierer et al. 2009; Waring et al. 2013; Chenet al. 2016; Bahram et al. 2018). For example, Bahramet al. (2018) also reported the inverse unimodal trend of BBC and positive linear trend of $\mathrm{F}: \mathrm{B}$ ratio along latitude and significant positive linear trend of F:B ratio along MAP and MAT, Fierer et al. (2009) reported significant controls of plant NPP and microbial biomass, Waring et al. (2013) showed that F:B ratio decreased with low level C:N ratio, and increased at high C:N ratio, and de Vrieset al. (2012) found that finely textured soils tend to have higher fungal and bacterial biomass.

In addition, we did find different results compared with previous studies. Specifically, in contrast to the inverse unimodal trend of FBC along latitude, Bahram et al. (2018) found the significant positive linear relationships between FBC and latitude. Also, we observed the inverse unimodal relationship between F:B ratio and soil $\mathrm{pH}$, with lowest $\mathrm{F}: \mathrm{B}$ ratio at soil $\mathrm{pH}$ of 6.3 , while Chen et al.(2015) reported a significant positive relationship between F:B ratio and soil pH in Mongolian Plateau and Eskelinen et al. (2009) found a negative relationship between $\mathrm{F}: \mathrm{B}$ ratio and soil $\mathrm{pH}$ in the alpine tundra of northern Europe. These discrepancies may result from two reasons. First, the difference in sample size may lead to the variations in the relationships obtained among studies. Dataset in Bahram et al. (2018) was built based on the globally selective sampling plots (145 topsoil samples), while the dataset of this study is a comprehensive meta-analysis dataset with 1323 data points (Fig. 1 ). Second, the difference in spatial scales of research is responsible for the plausible distinction. Chen et al. (2015) covered soil $\mathrm{pH}>6.5$, while Eskelinen et al. (2009) contained sampling sites of soil $\mathrm{pH}$ ranging from 4.7 to 7.0. Merging the negative and positive relationships between $\mathrm{F}$ : $\mathrm{B}$ ratio and soil pH found by Chen et al. (2015) and Eskelinen et al. (2009) reach the similar results as reported in this study.

FBC and BBC were largely distinct among biomes, but we observed generally similar patterns for FBC and BBC among biomes (Table 1 ). Consistent with our results, Xu et al. (2013) also found the highest soil microbial biomass in tundra among biomes, and soil microbial biomass was significantly higher in boreal forests than that in temperate forests and tropical/subtropical forests. Both Fiereret al. (2009) and Xu et al. (2013) reported lowest soil microbial biomass in deserts, the low SOC concentration may result in low FBC and BBC in deserts (Fig. S6 ). However, this study generated slightly different results from previous studies. Among forest biomes, Fierer et al. (2009) reported the higher soil microbial biomass in temperate and tropical forests than that in boreal forests, which exhibited opposite patterns with this study. In addition, soil microbial biomass in temperate forests was significantly higher than that in tropical/subtropical forests reported by $\mathrm{Xu}$ et al.(2013), while both FBC and BBC were significantly higher in tropical/subtropical forests than that in temperate forests in this study (Table 1 ). The seasonality of FBC and BBC could be a source for the inconsistency. Microbial biomass showed strong seasonal dynamics, samples taken in growing and non-growing seasons are expected to have distinct microbial biomass concentrations (Lipson et al.2002).

Our results also showed that F:B ratio was distinct among biomes, with the smallest F:B ratio in savanna and the highest in tundra (Table 1 ). Similar to our findings, Bahram et al. (2018) found significantly higher F:B ratio in boreal-arctic biomes (e.g., tundra and boreal forests) and temperate biomes (e.g., temperate forests and grassland) than that in tropical biomes (e.g., savanna and tropical/subtropical forests). Additionally, we found significantly higher F:B ratio in grasslands than that in pastures, which is consistent with de Vries et al. (2012), suggesting that management practices enhance the dominance of bacteria. 
We estimated FBC and BBC storage in topsoil as $12.56 \mathrm{Pg} \mathrm{C}$ and $4.34 \mathrm{Pg} \mathrm{C}$, respectively (Table 2 ). This result is consistent with overall terrestrial biomass estimates of $\mathrm{FBC}$ and $\mathrm{BBC}$ storage of $12 \mathrm{Pg} \mathrm{C}$ and $7 \mathrm{Pg}$ C, respectively, in Bar-On et al. (2018). Differences in methods probably account for most of the differences between the results reported in these studies. Fungi are more sensitive to anoxic conditions, and bacteria and archaea are important components in deep soils such as subsurface environments (Bar-On et al. 2018). It is likely that the differences in the soil depths between this study $(0-30 \mathrm{~cm})$ and Bar-On et al. (2018) (entire soil profile) might underpin the discrepancy in estimated global budget of BBC.

\section{Mechanisms for the Microbial Biogeography}

We demonstrated that different factors underpin the biogeographic patterns of $\mathrm{FBC}, \mathrm{BBC}$, and $\mathrm{F}: \mathrm{B}$ ratio in topsoil. These patterns can be related to the different nutrient stoichiometry of the microbial groups and their ecological tolerance. First, saprotrophic fungi have more efficient enzymatic machinery than bacteria to obtain C from complex organic material with high C:N ratio (de Vries et al. 2012; Chenet al. 2015). Second, highly carbon-rich soils usually display low soil $\mathrm{pH}$ that is relatively more difficult to cope with for bacteria compared with fungi (Eskelinen et al. 2009; Rousk et al.2010). These two interacting mechanisms may favor fungi-dominated ecosystem $\mathrm{C}$ and nutrient cycling in tundra and boreal forest ecosystems that exhibits particularly high F:B ratio. Third, fungi were more adapted to low-temperature conditions and more heat-tolerant than bacteria (Pietikainen et al. 2005). Meanwhile, fungi dominate early stages of litter decomposition that is more common in high-latitude than low-latitude (Steidinger et al. 2019). In concordance, we also found significantly higher F:B ratio in boreal forest and temperate forest than that in tropical/subtropical forest (Table 1 ). Grasslands feature significantly higher F:B ratio than pasture, indicating that management practices might enhance the dominance of bacteria as shown by de Vries et al. (2012). Natural wetland has F:B ratio comparable to unvegetated ground, desert, and shrub, which might be relevant to the low availability of oxygen that inhibits the growth of fungi and most soil bacteria (Lin et al.2012).

Edaphic properties rather than climatic variables determine much of the variation in FBC and BBC globally (Fig. 2a-b), which is consistent with Chen et al. (2016). This result indicates that FBC and BBC variations are driven by soil $\mathrm{pH}, \mathrm{SOC}$, nutrients (e.g., nitrogen and phosphorus), and soil texture (clay, silt, and sand) that control the availability of $\mathrm{C}$ energy, nutrients and oxygen - all determinants of fungal and bacterial growth (Brockett et al. 2012; de Vrieset al. 2012). Edaphic properties determine the nutrient and water availabilities, and even shelter from predation (Chapin et al.2011). Specifically, soil pH strongly influences abiotic factors, such as C availability (Andersson et al. 2000), nutrient availability (Pietri \& Brookes 2008), and the solubility of metals (Firestoneet al. 1983).

In striking contrast to bacterial and fungal biomass, our results suggest that climate is the most important factor governing the F:B ratio (Fig. 2c ). Climate has a principal effect on soil properties and vegetation activities that control soil microbial composition (Classen et al. 2015; Bahram et al. 2018). Although the tight association between plant community and soil microbial community structure has been reported (Bardgett et al.1998), we observed negligible effects of plant productivity (NPP and $\mathrm{C}_{\text {root }}$ ) on topsoil microbial community structure. It is likely due to two reasons: 1) we used plant productivity to represent the effect of plants in this study, while growing evidence points to plant functional traits as drivers of soil biological processes at a range of spatial scales (Bardgett \& Wardle 2010); 2) vegetation distribution and functional traits are largely determined by climate (Aerts 1997), the inclusion of both climate and plants into the model may result in the dominant role of climate in deciding soil microbial community.

\section{Implications for Global Carbon Cycle}

We estimated the ratio of $\mathrm{FBC}$ and $\mathrm{BBC}$ to $\mathrm{SOC}$ as $1.8 \%$ and $0.6 \%$, respectively, which agrees with the findings that microbial biomass C (MBC) generally comprises $0.5-5 \%$ of SOC (Insam 1990). Soil microbes, the living fraction of soil organic matter, have a much faster turnover rate than soil organic carbon (Xu et al. 
2017); meanwhile, the BBC bas faster turnover rate than FBC (Baath 1998; Rousk \& Baath 2007b). The changes in the MBC:SOC ratio indicates the integrated effects of soil organic matter input, soil microbial C use and $\mathrm{C}$ losses, and mineral protection of SOC; therefore, MBC:SOC ratio has been suggested as a useful and meaningful indicator of changes in soil organic matter status (Powlson \& Jenkinson 1981; Sparling 1992).

However, MBC:SOC ratio was not constant. In addition to the natural variations due to the seasonal dynamics of MBC, MBC:SOC ratio is affected by climate, and land use change, soil texture, soil mineralogy, and SOC (Sparling 1992). For example, managed ecosystems such as croplands and pastures tend to have broad MBC:SOC ratio and high MBC, the increasing $\mathrm{MBC}$ will enhance the release of carbon dioxide from soil to atmosphere due to the facilitated microbial breakdown of soil organic matter. The acceleration of such processes by soil microbes could significantly exacerbate the soil $\mathrm{C}$ cycle; therefore, soil microbial community change is expected to have profound influence on global $\mathrm{C}$ cycle.

\section{Limitations and Prospects}

A few limitations need to be recognized when interpreting the results. First, we assumed that all samples were taken from surface soil representing 0-30 cm soil profile; while the sampling depth varies between 0 and $30 \mathrm{~cm}$ in this study, and $76 \%$ of soil samples were taken for topsoil of $0-15 \mathrm{~cm}$. Considering the vertical distribution of microbial biomass $\mathrm{C}$ (Xu et al. 2013), this bias might lead to a trivial overestimate to the summarized BBC and FBC in our estimates. Second, the disproportion of the number of data points from each biome to its land area might lead to bias in spatial extrapolation. For example, the data points from forest, grassland, and cropland contribute approximately $80 \%$ of the dataset, while the land area of these biomes is approximately $50 \%$ of the global land area (Table 2 ). Third, the sampling date might be another reason for uncertainty; the data points were taken from various seasons and we assume the average across season represent the annual mean. In this aspect, future studies on seasonal variation of soil FBC and BBC would bring in improvements to our knowledge. Fourth, actinobacteria was categorized as bacteria in a portion of studies but not in others (Andersen et al. 2010; Royer-Tardif et al. 2010). This difference in classification may introduce minor uncertainties in simulating the relationships between FBC and BBC.

\section{Conclusions}

This study reports the BBC and FBC in main biomes and presents the first global maps of $\mathrm{BBC}$ and FBC in $0-30 \mathrm{~cm}$ topsoil. The global FBC and $\mathrm{BBC}$ were estimated to be $12.56(6.64 \sim 16.42) \mathrm{Pg} \mathrm{C}$ and $4.34\left(0.47^{\sim} 10.26\right) \mathrm{Pg} \mathrm{C}$, respectively, in $0-30 \mathrm{~cm}$ topsoil. The $\mathrm{FBC}, \mathrm{BBC}$, and F:B ratio showed clear distribution patterns on a global scale. Significant trends were observed along meteorological parameters (MAP, MAT, ST, and SM), vegetation productivity $\left(\mathrm{C}_{\text {root }}\right.$ and $\mathrm{NPP}$ ), and edaphic properties (soil texture, bulk density, soil $\mathrm{pH}, \mathrm{SOC}, \mathrm{TN}$, and $\mathrm{C}: \mathrm{N}$ ratio). The $\mathrm{FBC}$ and $\mathrm{BBC}$ were primarily determined by edaphic properties including sol texture, soil $\mathrm{pH}$, bulk density, and $\mathrm{SOC}$, the $\mathrm{F}: \mathrm{B}$ ratio was mostly driven by climatic variables, particularly MAP and MAT. The biogeographic patterns of BBC and FBC suggest that multiple mechanisms synergistically affect soil $\mathrm{C}$ and nutrient cycling globally. Our study creates a benchmark for explicit use of microbial distribution and its underlying mechanisms for predicting soil $\mathrm{C}$ and nutrient cycling and biosphere-atmosphere feedbacks in a changing climate.

\section{Acknowledgements}

This study is partially supported by San Diego State University. Financial assistance was partially provided by the SPRUCE and NGEE Arctic projects, which are supported by the Office of Biological and Environmental Research in the Department of Energy Office of Science. This study was partially supported by the Northeast Institute of Geography and Agroecology, Chinese Academy of Sciences, and the "Top Notch" program in China. C.S. is supported by the National Natural Science Foundation of China (41125001). X.X. acknowledge the financial support from the San Diego State University and the CSU Program for Education 
\& Research in Biotechnology. N.S. was supported by VIDI grant 016.161.318 issued by the Netherlands Organization of Scientific Research.

\section{Author Contributions}

X.X. conceived the project. L.H. performed the data compilation. N.A.S, M.B, P.A.O., C.S., Y.S., L.T contributed data. L.H. and X.X. developed the empirical model and carried out the model simulation. F.H.Y. and F.M.Y contributed to data analysis. L.H., J.L.M.R., D.L., and X.X. interpreted the results. L.H. and X.X. wrote the manuscript with assistances from other coauthors.

\section{Additional Information}

Supplementary Information accompanies this paper at https://doi.org/...

Competing interests: The authors declare no competing interests.

Reprints and permission information is available online at ??????

\section{Data Availability}

The data used in this study will be archived at Dryad when this paper is accepted. The data sources for the meteorology, soil properties and microbial properties can be found in the Materials and Methods section.

\section{Code Availability}

The code for data analysis and producing global maps for the bacteria and fungi can be accessed upon request to L.H. and X.X.

\section{Reference}

1.

Aerts, R. (1997). Climate, leaf litter chemistry and leaf litter decomposition in terrestrial ecosystems. Oikos , 79, 439-449.

2 .

Andersen, R., Grasset, L., Thormann, M.N., Rochefort, L. \& Francez, A.-J. (2010). Changes in microbial community structure and function following Sphagnum peatland restoration. Soil Biology and Biochemistry , 42, 291-301.

3.

Andersson, S., Nilsson, S.I. \& Saetre, P. (2000). Leaching of dissolved organic carbon (DOC) and dissolved organic nitrogen (DON) in mor humus as affected by temperature and pH. Soil Biology and Biochemistry, $32,1-10$.

4 .

Aon, M.A., Cabello, M.N., Sarena, D.E., Colaneri, A.C., Franco, M.G., Burgos, J.L. et al. (2001). I. Spatiotemporal patterns of soil microbial and enzymatic activities in an agricultural soil.Applied Soil Ecology , 18, 239-254.

5 . 
Baath, E. (1998). Growth rates of bacterial communities in soils at varying $\mathrm{pH}$ : a comparison of the thymidine and leucine incorporation techniques. Microbial Ecology , 36, 316-327.

6.

Bahram, M., Hildebrand, F., Forslund, S.K., Anderson, J.L., Soudzilovskaia, N.A., Bodegom, P.M. et al. (2018). Structure and function of the global topsoil microbiome. Nature, 560, 233.

7.

Bar-On, Y.M., Phillips, R. \& Milo, R. (2018). The biomass distribution on Earth. Proceedings of the National Academy of Sciences, 115, 6506-6511.

8.

Bardgett, R.D. \& Wardle, D.A. (2010). Aboveground-belowground linkages: biotic interactions, ecosystem processes, and global change. Oxford University Press.

9.

Bardgett, R.D., Wardle, D.A. \& Yeates, G.W. (1998). Linking above-ground and below-ground interactions: how plant responses to foliar herbivory influence soil organisms. Soil Biology and Biochemistry, 30, 18671878 .

10.

Beare, M.H., Neely, C.L., Coleman, D.C. \& Hargrove, W.L. (1990). A substrate-induced respiration (SIR) method for measurement of fungal and bacterial biomass on plant residues. Soil Biology and Biochemistry $, 22,585-594$.

11.

Birkhofer, K., Bezemer, T.M., Bloem, J., Bonkowski, M., Christensen, S., Dubois, D. et al. (2008). Longterm organic farming fosters below and aboveground biota: Implications for soil quality, biological control and productivity. Soil Biology and Biochemistry, 40, 2297-2308.

12.

Brockett, B.F.T., Prescott, C.E. \& Grayston, S.J. (2012). Soil moisture is the major factor influencing microbial community structure and enzyme activities across seven biogeoclimatic zones in western Canada.Soil Biology and Biochemistry , 44, 9-20.

13.

Caldwell, B.A. (2005). Enzyme activities as a component of soil biodiversity: a review. Pedobiologia , 49, 637-644.

14.

Chapin, F.S., Matson, P.A. \& Vitousek, P. (2011). Principles of terrestrial ecosystem ecology . Springer Science \& Business Media.

15.

Chen, D., Mi, J., Chu, P., Cheng, J., Zhang, L., Pan, Q. et al.(2015). Patterns and drivers of soil microbial communities along a precipitation gradient on the Mongolian Plateau. Landscape Ecology, 30, 1669-1682.

16.

Chen, Y.-L., Ding, J.-Z., Peng, Y.-F., Li, F., Yang, G.-B., Liu, L.et al. (2016). Patterns and drivers of soil microbial communities in Tibetan alpine and global terrestrial ecosystems. Journal of Biogeography , 43, 2027-2039. 
17.

Classen, A.T., Sundqvist, M.K., Henning, J.A., Newman, G.S., Moore, J.A., Cregger, M.A. et al. (2015). Direct and indirect effects of climate change on soil microbial and soil microbial-plant interactions: What lies ahead? Ecosphere, 6, 1-21.

18.

Crowther, T.W., Hoogen, J.v.d., Wan, J., Mayes, M.A., Keiser, A.D., Mo, L. et al. (2019). The global soil community and its influence on biogeochemistry. Science, 365, eaav0550.

19.

de Vries, F.T., Manning, P., Tallowin, J.R.B., Mortimer, S.R., Pilgrim, E.S., Harrison, K.A. et al. (2012). Abiotic drivers and plant traits explain landscape-scale patterns in soil microbial communities.Ecology letters , 15, 1230-1239.

20.

DeLong, E.F., Harwood, C.S., Chisholm, P.W., Karl, D.M., Moran, M.A., Schmidt, T.M. et al. (2011). Incorporating microbial processes into climate models. The American Academy of Microbiology Washington DC.

21.

Ding, J., Zhang, Y., Wang, M., Sun, X., Cong, J., Deng, Y. et al.(2015). Soil organic matter quantity and quality shape microbial community compositions of subtropical broadleaved forests. Mol Ecol , 24, 5175-5185.

22.

Eskelinen, A., Stark, S. \& Mannisto, M. (2009). Links between plant community composition, soil organic matter quality and microbial communities in contrasting tundra habitats. Oecologia , 161, 113-123.

23.

Falkowski, P.G., Fenchel, T. \& Delong, E.F. (2008). The microbial engines that drive Earth's biogeochemical cycles. Science, 320, 1034-1039.

24.

Fierer, N. \& Jackson, R.B. (2006). The diversity and biogeography of soil bacterial communities. Proceedings of the National Academy of Sciences, 103, 626-631.

25.

Fierer, N., Strickland, M.S., Liptzin, D., Bradford, M.A. \& Cleveland, C.C. (2009). Global patterns in belowground communities. Ecology letters, 12, 1238-1249.

26.

Firestone, M.K., Killham, K. \& McColl, J.G. (1983). Fungal toxicity of mobilized soil aluminum and manganese. Appl. Environ. Microbiol. , 46, 758-761.

27.

Frostegard, a., A. A. \& Baath, E. (1996). The use of phospholipid fatty acid analysis to estimate bacterial and fungal biomass in soil.Biology and Fertility of Soils , 22, 59-65.

28.

Haefner, J.W. (2005). Modeling biological systems-principles and applications . Springer, New York. 
29.

Hanson, C.A., Fuhrman, J.A., Horner-Devine, M.C. \& Martiny, J.B. (2012). Beyond biogeographic patterns: processes shaping the microbial landscape. Nature Review Microbiology , 10, 496-506.

30.

Hogberg, P., Nordgren, A., Buchmann, N., Taylor, A.F.S., Ekblad, A., Hogberg, M.N. et al. (2001). Largescale forest girdling shows that current photosynthesis drives soil respiration. Nature, 411, 789.

31.

Insam, H. (1990). Are the soil microbial biomass and basal respiration governed by the climatic regime? Soil Biology and Biochemistry, 22, 525-532.

32.

Jost, D.I., Indorf, C., Joergensen, R.G. \& Sundrum, A. (2011). Determination of microbial biomass and fungal and bacterial distribution in cattle faeces. Soil Biology and Biochemistry , 43, 1237-1244.

33.

Klamer, M. \& Baath, E. (2004). Estimation of conversion factors for fungal biomass determination in

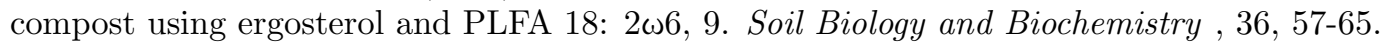

34.

Lin, X., Green, S., Tfaily, M.M., Prakash, O., Konstantinidis, K.T., Corbett, J.E. et al. (2012). Microbial community structure and activity linked to contrasting biogeochemical gradients in bog and fen environments of the Glacial Lake Agassiz Peatland. Appl. Environ. Microbiol. , 78, 7023-7031.

35.

Lipson, D.A., Schadt, C.W. \& Schmidt, S.K. (2002). Changes in soil microbial community structure and function in an alpine dry meadow following spring snow melt. Microbial ecology, 43, 307-314.

36.

Martiny, J.B.H., Bohannan, B., J. M., Brown, J.H., Colwell, R.K., Fuhrman, J.A., Green, J.L. et al. (2006). Microbial biogeography: putting microorganisms on the map. Nature Review Microbiology , 4, 102-112.

37.

Mouginot, C., Kawamura, R., Matulich, K.L., Berlemont, R., Allison, S.D., Amend, A.S. et al. (2014). Elemental stoichiometry of Fungi and Bacteria strains from grassland leaf litter. Soil Biology and Biochemistry , 76, 278-285.

38.

Pietikäinen, J., Pettersson, M. \& Bååth, E. (2005). Comparison of temperature effects on soil respiration and bacterial and fungal growth rates. FEMS Microbiology Ecology, 52, 49-58.

39.

Pietri, J.C.A. \& Brookes, P.C. (2008). Nitrogen mineralisation along a pH gradient of a silty loam UK soil. Soil Biology and Biochemistry , 40, 797-802.

40.

Powlson, D.S. \& Jenkinson, D.S. (1981). A comparison of the organic matter, biomass, adenosine triphosphate and mineralizable nitrogen contents of ploughed and direct-drilled soils. The Journal of Agricultural Science , 97, 713-721. 
41.

Rillig, M.C. \& Mummey, D.L. (2006). Mycorrhizas and soil structure.New Phytologist, 171, 41-53.

42.

Rousk, J. \& Bååth, E. (2007a). Fungal and bacterial growth in soil with plant materials of different C/N ratios. FEMS Microbiology Ecology, 62, 258-267.

43.

Rousk, J. \& Bååth, E. (2007b). Fungal biomass production and turnover in soil estimated using the acetatein-ergosterol technique. Soil Biology and Biochemistry, 39, 2173-2177.

44.

Rousk, J., Brookes, P.C. \& Baath, E. (2009). Contrasting soil pH effects on fungal and bacterial growth suggest functional redundancy in carbon mineralization. Applied and Environmental Microbiology , 75, 15891596 .

45.

Rousk, J., Brookes, P.C. \& Bååth, E. (2010). Investigating the mechanisms for the opposing pH relationships of fungal and bacterial growth in soil. Soil Biology and Biochemistry , 42, 926-934.

46.

Royer-Tardif, S., Bradley, R. \& Parsons, W. (2010). Evidence that plant diversity and site productivity confer stability to forest floor microbial biomass. Soil Biology and Biochemistry, 42, 813-821.

47.

Ruesch, A. \& Gibbs, H.K. (2008). New IPCC Tier-1 global biomass carbon map for the year 2000. Available online from the Carbon Dioxide Information Analysis Center [http://cdiac. ornl. gov], Oak Ridge National Laboratory, Oak Ridge, Tennessee .

48.

Schimel, J.P. \& Schaeffer, S.M. (2012). Microbial control over carbon cycling in soil. Frontiers in Microbiology , 3, 1-11.

49.

Six, J., Frey, S.D., Thiet, R.K. \& Batten, K.M. (2006). Bacterial and fungal contributions to carbon sequestration in agroecosystems. Soil Science Society of America Journal , 70, 555-569.

50.

Song, X., Hoffman, F.M., Iversen, C.M., Yin, Y., Kumar, J., Ma, C.et al. (2017). Significant inconsistency of vegetation carbon density in CMIP5 Earth system models against observational data. Journal of Geophysical Research: Biogeosciences, 122, 2282-2297.

51.

Sparling, G.P. (1992). Ratio of microbial biomass carbon to soil organic carbon as a sensitive indicator of changes in soil organic matter.Soil Research, 30, 195-207.

52.

Steidinger, B.S., Crowther, T.W., Liang, J., Van Nuland, M.E., Werner, G.D., Reich, P.B. et al. (2019). Climatic controls of decomposition drive the global biogeography of forest-tree symbioses. Nature , 569, 404408. 
53.

Turner, B.L., Lambers, H., Condron, L.M., Cramer, M.D., Leake, J.R., Richardson, A.E. et al. (2013). Soil microbial biomass and the fate of phosphorus during long-term ecosystem development. Plant and Soil , $367,225-234$.

54.

van der Heijden, M.G.A., Bardgett, R.D. \& Van Straalen, N.M. (2008). The unseen majority: soil microbes as drivers of plant diversity and productivity in terrestrial ecosystems. Ecology letters , 11, 296-310.

55.

Waring, B.G., Averill, C. \& Hawkes, C.V. (2013). Differences in fungal and bacterial physiology alter soil carbon and nitrogen cycling: insights from meta-analysis and theoretical models. Ecology letters , 16, 887-894.

56.

Wieder, W.R., Bonan, G.B. \& Allison, S.D. (2013). Global soil carbon projections are improved by modelling microbial processes. Nature Climate Change , 3, 909-912.

57.

$\mathrm{Xu}, \mathrm{X}$. (2010). Modeling methane and nitrous oxide exchanges between the atmosphere and terrestrial ecosystems over North America in the context of multifactor global change. In: School of Forestry and Wildlife Sciences. Auburn University Auburn, p. 199.

58.

Xu, X., Schimel, J.P., Janssens, I.A., Song, X., Song, C., Yu, G.et al. (2017). Global pattern and controls of soil microbial metabolic quotient. Ecological Monographs , 87, 429-441.

59.

Xu, X., Schimel, J.P., Thornton, P.E., Song, X., Yuan, F. \& Goswami, S. (2014). Substrate and environmental controls on microbial assimilation of soil organic carbon: a framework for Earth system models. Ecology Letters , 17, 547-555.

60.

Xu, X., Thornton, P.E. \& Post, W.M. (2013). A global analysis of soil microbial biomass carbon, nitrogen and phosphorus in terrestrial ecosystems. Global Ecology and Biogeography, 22, 737-749. 


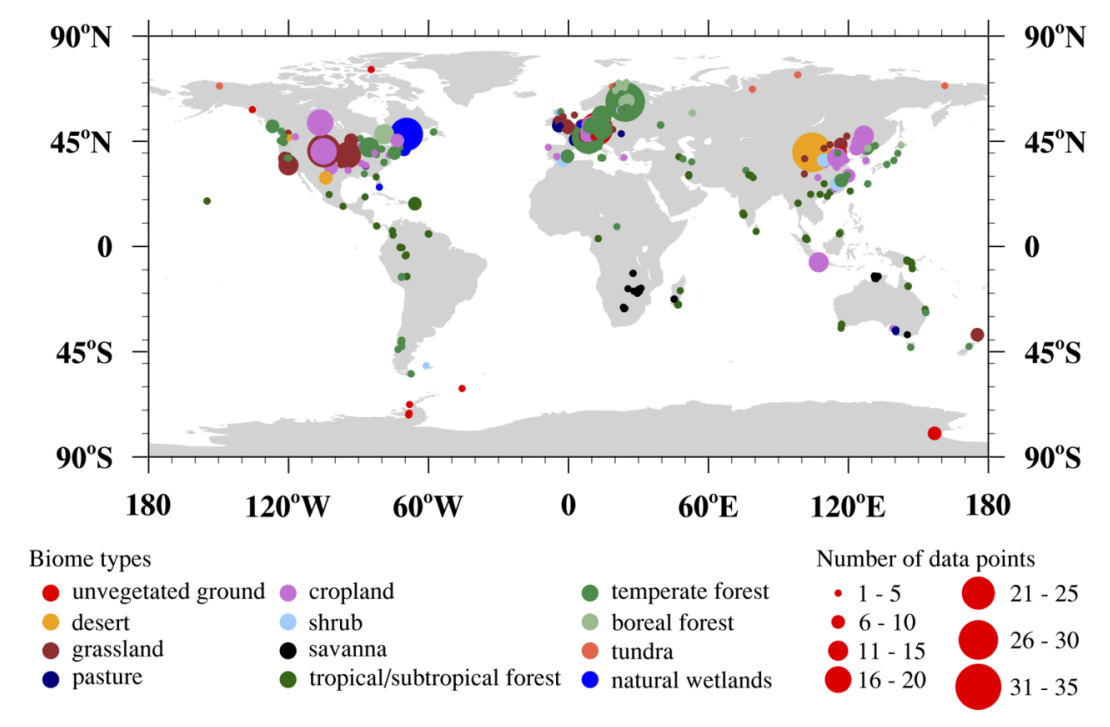

Fig. 1 Global distribution of data points included in this analysis. 1323 data points with geographical coordinates are shown in this map. Circles indicate study sites, with circles in different sizes showing variation in the number of data points and different colors representing different biomes

Table 1. Biome-level fungal biomass carbon (FBC), bacterial biomass carbon (BBC,) and fungi:bacteria (F:B) ratio

\begin{tabular}{|c|c|c|c|}
\hline Biome & FBC (mg kg${ }^{-1}$ soil $)$ & BBC (mg kg ${ }^{-1}$ soil $)$ & $\mathrm{F}: \mathrm{B}$ ratio \\
\hline Unvegetated ground & $192.74^{\text {de }}(54.79 \sim 677.99)$ & $24.6^{\mathrm{d}}\left(7.68^{\sim} 78.72\right)$ & $3.9^{\mathrm{bc}}\left(2.2^{\sim} 6.91\right)$ \\
\hline Desert & $16.92^{\mathrm{f}}(14.4 \sim 19.89)$ & $6.83^{\mathrm{e}}(6.1 \sim 7.65)$ & $3.14^{\text {bcd }}\left(2.2^{\sim} 4.49\right)$ \\
\hline Grassland & $215.19^{\text {de }}(168.98 \sim 274.03)$ & $62.69^{\text {cd }}(50.44 \sim 77.92)$ & $4.03^{\mathrm{b}}\left(3.52^{\sim} 4.62\right)$ \\
\hline Pasture & $632.15^{\mathrm{bc}}(288.99 \sim 1382.81)$ & $270.65^{\mathrm{a}}\left(129.07^{\sim} 567.53\right)$ & $2.48^{\text {cde }}\left(1.62^{\sim} 3.8\right)$ \\
\hline Cropland & $212.69^{\text {de }}(150.35 \sim 300.88)$ & $65.77^{\mathrm{cd}}(46.3 \sim 93.42)$ & $3.28^{\text {bcd }}(2.89 \sim 3.73)$ \\
\hline Shrub & $218.14^{\text {cde }}(106.01 \sim 448.9)$ & $45.42^{\text {cd }}(23.48 \sim 87.85)$ & $4.82^{\mathrm{b}}(3.72 \sim 6.25)$ \\
\hline Savanna & $103.36^{\mathrm{e}}(60.62 \sim 176.23)$ & $44.37^{\mathrm{cd}}\left(25.94^{\sim} 75.92\right)$ & $1.82^{\mathrm{e}}\left(1.57^{\sim} 2.11\right)$ \\
\hline Tropical/subtropical forest & $451.40^{\mathrm{bc}}(362.32 \sim 562.39)$ & $209.96^{\mathrm{ab}}(179.03 \sim 246.24)$ & $2.22^{\text {de }}(1.87 \sim 2.63)$ \\
\hline Temperate forest & $258.39^{\text {de }}(189.16 \sim 352.95)$ & $53.05^{\mathrm{cd}}(38.71 \sim 72.7)$ & $4.92^{\mathrm{b}}(4.39 \sim 5.51)$ \\
\hline Boreal forest & $1234.08^{\mathrm{b}}(870.72 \sim 1749.08)$ & $226.37^{\mathrm{ab}}(172.79 \sim 296.58)$ & $5.03^{\mathrm{b}}(4.23 \sim 5.98)$ \\
\hline Tundra & $3683.59^{\mathrm{a}}\left(1678.49^{\sim}\right.$ 8083.94) & $428.37^{\mathrm{a}}\left(236.98^{\sim} 774.31\right)$ & $8.6^{\mathrm{a}}\left(6.71^{\sim} 11.01\right)$ \\
\hline Natural wetlands & $329.81^{\text {cde }}\left(194.8^{\sim} 558.4\right)$ & $92.58^{\text {bc }}(50.99 \sim 168.1)$ & $4.13^{\mathrm{b}}\left(3.5^{\sim} 4.86\right)$ \\
\hline
\end{tabular}

* Values are presented as means with a $95 \%$ confidence boundary in parentheses and number of data points for fungal, bacterial biomass and F:B ratio in brackets. Different superscript letters in one column mean significant difference at the significance level of $P=0.05$, while the same letters indicate no significant difference 
Fungal biomass carbon (log-scaled)

a

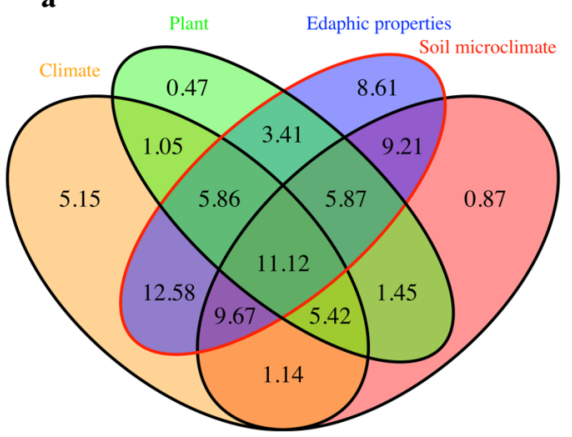

\section{Bacterial biomass carbon (log-scaled)}

b

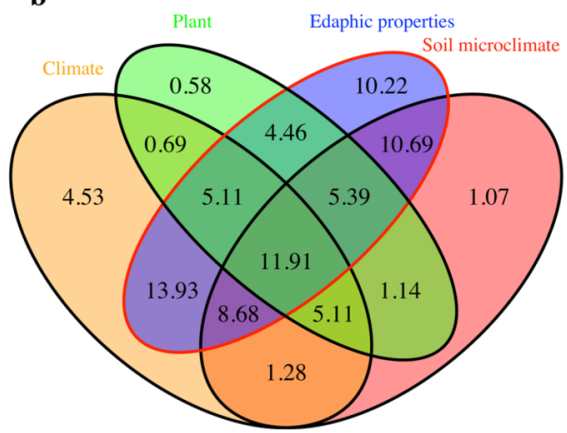

\section{F:B biomass carbon ratio (log-scaled)}

.

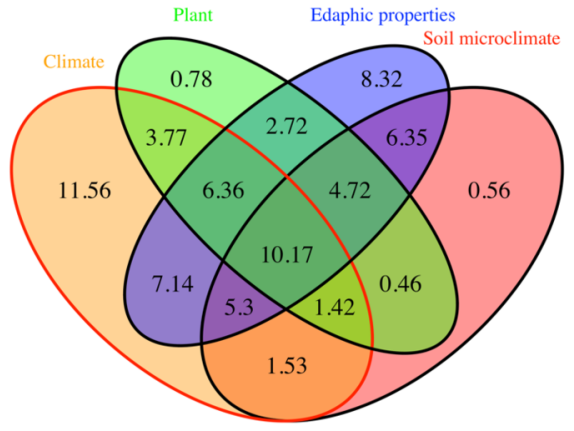

Fig. 2 Interactive effects of climate, plant, edaphic properties, and soil microclimate on (a) fungal biomass carbon $(n=611)$, (b) bacterial biomass carbon $(n=619)$, and (c) $F: B$ ratio $(n=748)$; Climate includes MAT and MAP; Plant represent combined information of $\mathrm{C}_{\text {root }}$ and NPP; Edaphic properties includes bulk density, soil pH, SOC, ST, clay, and sand. Soil microclimate represents ST and SM (red ellipse indicates the dominant group of variables) 

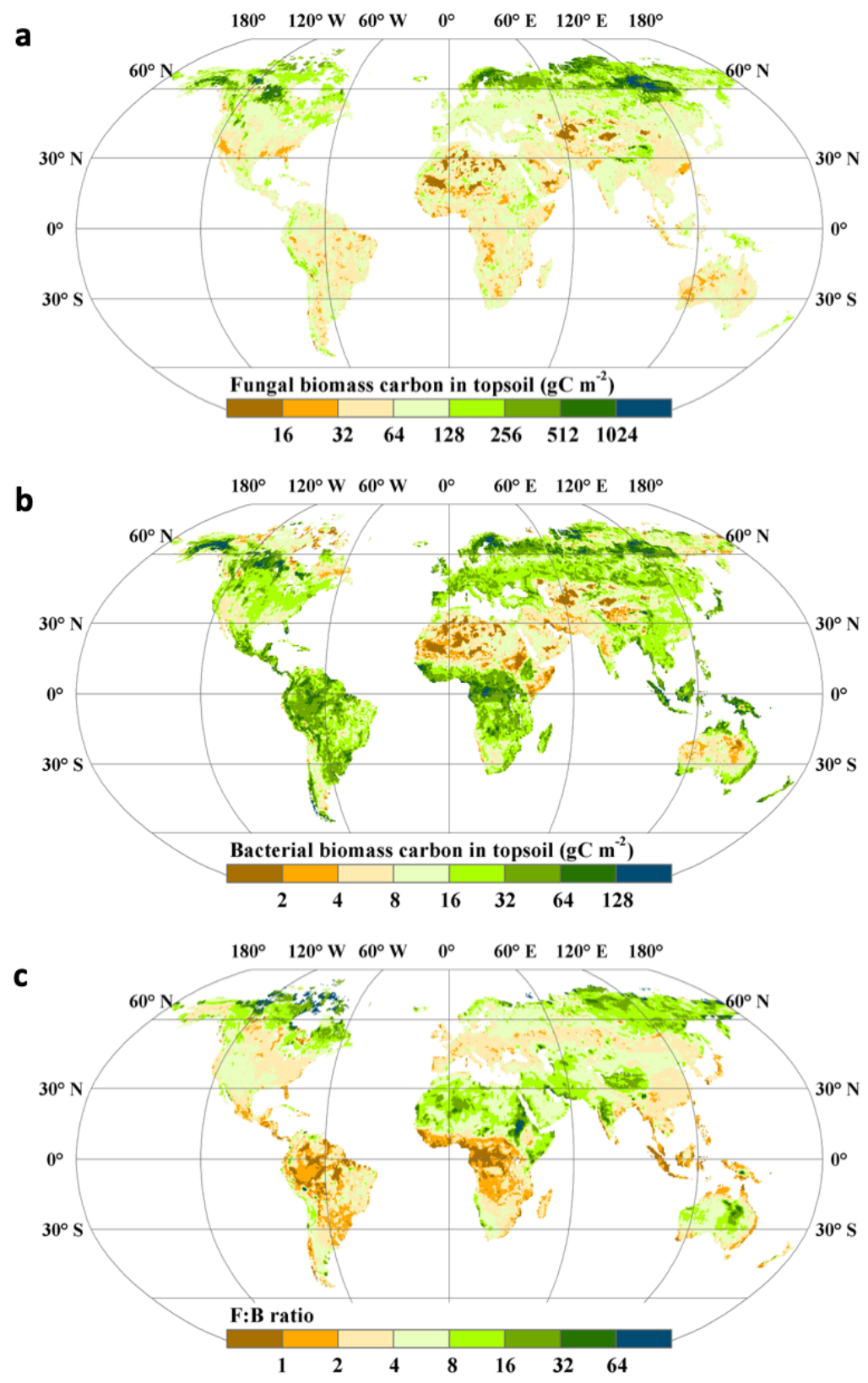

Fig. 3 Global maps of (a) fungal biomass C, (b) bacterial biomass C, and (c) F:B ratio in topsoil

Table 2. Biome-and global level storage and density of soil fungal and bacterial biomass C (95\% confidence interval are shown in the bracket)

\begin{tabular}{lllll}
\hline & Area $\left(\right.$ million $\left.\mathrm{km}^{2}\right)$ & Biomass C Density $\left(\mathrm{g} \mathrm{C} \mathrm{m}^{-2}\right)$ & Biomass C Density $\left(\mathrm{g} \mathrm{C} \mathrm{m}^{-2}\right)$ & Biomass \\
\hline Biome & & Fungi & Bacteria & Fungi \\
Boreal forest & 11.82 & $304.44(191.19-356.01)$ & $58.66(7.02-171.86)$ & $3.6(2.2$ \\
Temperate forest & 12.89 & $88.89(40.25-115.74)$ & $29.88(3.01-78.5)$ & $1.15(0)$. \\
Tropical/Subtropical forest & 16.44 & $64.42(2.09-115.49)$ & $51.58(0.51-113.82)$ & $1.06(0$.
\end{tabular}




\begin{tabular}{lllll}
\hline & Area $\left(\right.$ million $\left.\mathrm{km}^{2}\right)$ & Biomass C Density $\left(\mathrm{g} \mathrm{C} \mathrm{m}^{-2}\right)$ & Biomass C Density $\left(\mathrm{g} \mathrm{C} \mathrm{m}^{-2}\right)$ & Biomass \\
\hline Grassland & 12.16 & $88.69(20.55-132.48)$ & $46.14(2.34-114.23)$ & $1.08(0$. \\
Shrub & 8.11 & $48.06(11.4-64.78)$ & $17.31(0.59-53.85)$ & $0.39(0$. \\
Tundra & 5.75 & $226.96(150.89-256.46)$ & $32.65(3.13-108.08)$ & $1.31(0$. \\
Desert & 13.51 & $59.04(14.05-74)$ & $15.28(0.32-60.21)$ & $0.8(0.1)$ \\
Natural wetlands & 6.91 & $70.44(30.9-99.91)$ & $32.96(3.47-72.44)$ & $0.49(0)$. \\
Cropland & 14.94 & $67.61(18.18-95.92)$ & $30.09(1.73-79.35)$ & $1.01(0)$. \\
Pasture & 27.00 & $62.34(24.03-84.12)$ & $23.68(1.85-61.62)$ & $1.68(0$. \\
Globe & 129.55 & $96.92(51.23-126.75)$ & $33.5(3.66-79.19)$ & $12.56(6$ \\
\hline
\end{tabular}

